\title{
Front Matter: Volume 6572
}

, "Front Matter: Volume 6572," Proc. SPIE 6572, Enabling Photonics Technologies for Defense, Security, and Aerospace Applications III, 657201 (21 April 2009); doi: 10.1117/12.741112

SPIE Event: Defense and Security Symposium, 2007, Orlando, Florida, United SPIE. States 


\title{
PROCEEDINGS OF SPIE
}

\section{Enabling Photonics Technologies for Defense, Security, and Aerospace Applications III}

\author{
Michael J. Hayduk \\ Andrew R. Pirich \\ Peter J. Delfyett, Jr. \\ Eric J. Donkor \\ John P. Barrios \\ Rebecca J. Bussjager \\ Michael L. Fanto \\ Robert L. Kaminski \\ Guifang Li \\ Hooman Mohseni \\ Edward W. Taylor \\ Editors \\ 9-10 April 2007 \\ Orlando, Florida, USA \\ Sponsored and Published by \\ SPIE-The International Society for Optical Engineering
}

Volume 6572

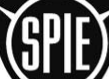

The International Society

for Optical Engineering

Proceedings of SPIE-The International Society for Optical Engineering, 9780819466945, v. 6572

SPIE is an international technical society dedicated to advancing engineering and scientific applications of optical, photonic, imaging, electronic, and optoelectronic technologies. 
The papers included in this volume were part of the technical conference cited on the cover and title page. Papers were selected and subject to review by the editors and conference program committee. Some conference presentations may not be available for publication. The papers published in these proceedings reflect the work and thoughts of the authors and are published herein as submitted. The publisher is not responsible for the validity of the information or for any outcomes resulting from reliance thereon.

Please use the following format to cite material from this book:

Author(s), "Title of Paper," in Enabling Photonics Technologies for Defense, Security, and Aerospace Applications III, edited by Michael J. Hayduk, Andrew R. Pirich, Peter J. Delfyett, Jr., Eric J. Donkor, John P. Barrios, Rebecca J. Bussjager, Michael L. Fanto, Robert L. Kaminski, Guifang Li, Hooman Mohseni, Edward W. Taylor, Proceedings of SPIE Vol. 6572 (SPIE, Bellingham, WA, 2007) Article CID Number.

ISSN 0277-786X

ISBN 9780819466945

Published by

SPIE-The International Society for Optical Engineering

P.O. Box 10, Bellingham, Washington 98227-0010 USA

Telephone 1 360/676-3290 (Pacific Time) · Fax 1 360/647-1445

http://www.spie.org

Copyright (C) 2007, The Society of Photo-Optical Instrumentation Engineers

Copying of material in this book for internal or personal use, or for the internal or personal use of specific clients, beyond the fair use provisions granted by the U.S. Copyright Law is authorized by SPIE subject to payment of copying fees. The Transactional Reporting Service base fee for this volume is $\$ 18.00$ per article (or portion thereof), which should be paid directly to the Copyright Clearance Center (CCC), 222 Rosewood Drive, Danvers, MA 01923. Payment may also be made electronically through CCC Online at http://www.copyright.com. Other copying for republication, resale, advertising or promotion, or any form of systematic or multiple reproduction of any material in this book is prohibited except with permission in writing from the publisher. The CCC fee code is $0277-786 \times / 07 / \$ 18.00$.

Printed in the United States of America. 


\section{Contents}

vii Conference Committee

\section{SESSION 1 COHERENT OPTICAL COMMUNICATIONS}

657202 DSP-enabled coherent optical communications (Invited Paper) [6572-01]

G. Goldfarb, G. Li, College of Optics and Photonics, Univ. of Central Florida (USA)

657203 All-optical carrier phase and polarization recovery for coherent optical communications [6572-02]

I. Kim, K. Croussore, X. Li, G. Li, College of Optics and Photonics, Univ. of Central Florida (USA)

657204 Coherent optical receiver with widely tunable local oscillator laser [6572-03]

C. Wree, D. Mohr, D. Becker, A. Joshi, Discovery Semiconductors, Inc. (USA)

657205 All-optical regeneration of differential phase-shift keyed signals [6572-04]

K. Croussore, G. Li, College of Optics and Photonics, Univ. of Central Florida (USA)

\section{SESSION 2 RF PHOTONICS}

65720740 GSPS opto-electronic polyphase analog-to-digital converter [6572-06] C. Villa, E. Donkor, Univ. of Connecticut (USA); M. Hayduk, R. Bussjager, Air Force Research Lab. (USA)

657208 Programmable microwave transversal filter using acousto-optic tunable filtering [6572-07] F. N. Ghauri, N. A. Riza, College of Optics and Photonics, Univ. of Central Florida (USA)

Pagination: Proceedings of SPIE follow an e-First publication model, with papers published first online and then in print and on CD-ROM. Papers are published as they are submitted and meet publication criteria. A unique, consistent, permanent citation identifier (CID) number is assigned to each article at the time of the first publication. Utilization of CIDs allows articles to be fully citable as soon they are published online, and connects the same identifier to all online, print, and electronic versions of the publication.

SPIE uses a six-digit CID article numbering system in which:

- The first four digits correspond to the SPIE volume number.

- The last two digits indicate publication order within the volume using a Base 36 numbering system employing both numerals and letters. These two-number sets start with 00, 01, 02, 03, 04, 05, 06, 07, 08, 09, 0A, OB ... 0Z, followed by 10-1Z, 20-2Z, etc.

The CID number appears on each page of the manuscript. The complete citation is used on the first page, and an abbreviated version on subsequent pages. 
657209 Time reversed photonic beamforming of arbitrary waveform ladar arrays (Invited Paper) [6572-08]

J. L. Cox, Air Force Space and Missile Systems Ctr. (USA); H. Zmuda, Univ. of Florida (USA);

R. J. Bussjaeger, R. K. Erdmann, M. L. Fanto, M. J. Hayduk, J. E. Malowicki, Air Force

Research Lab. (USA)

\section{SESSION $3 \quad$ MODE-LOCKED LASERS AND OPTICAL SOURCES}

65720A Control over spectral content via differential pumping of a monolithic passively mode locked quantum dot laser [6572-09]

K. Brown, B. Wysocki, M. Fanto, J. Malowicki, V. Kovanis, Air Force Research Lab. (USA);

L. Lester, Ctr. for High Technology Materials, Univ. of New Mexico (USA)

65720B Semiconductor-based high repetition rate mode-locked lasers for time and frequencybased coherent communications and signal processing applications (Invited Paper) [6572-10]

F. Quinlan, S. Gee, S. Ozharar, P. J. Delfyett, Jr., College of Optics and Photonics, Univ. of Central Florida (USA)

65720C Ultrastable harmonically mode-locked erbium-doped waveguide laser [6572-11] M. L. Fanto, R. K. Erdmann, B. T. Wysocki, J. E. Malowicki, T. A. McEwen, Air Force Research Lab. (USA)

\section{SESSION 4 OPTICAL DETECTORS AND ARRAYS}

$65720 \mathrm{E}$ Multimode fibered photodetectors for high-power high-speed applications beyond $10 \mathrm{~Gb} / \mathrm{s}$ [6572-13]

R. Howard, X. Wang, A. Joshi, D. Becker, S. Datta, C. Wree, Discovery Semiconductors, Inc. (USA)

$65720 \mathrm{G}$ InGaAsP avalanche photodetectors for non-gated $1.06 \mu \mathrm{m}$ photon-counting receivers [6572-15]

M. A. Itzler, X. Jiang, R. Ben-Michael, K. Slomkowski, Princeton Lightwave Inc. (USA);

M. A. Krainak, S. WU, X. Sun, NASA Goddard Space Flight Ctr. (USA)

$65720 \mathrm{H}$ Linear-mode single photon counting APD arrays with subnanosecond afterpulse-free performance for ladar, spectroscopy, and QKD applications [6572-16]

L. Aina, A. Fathimulla, H. Hier, M. Lecates, R. Dwarkin, D. Johnson, Epitaxial Technology, LLC (USA); S. Babu, NASA Goddard Space Flight Ctr. (USA); J. Foshee, Air Force Research Lab. (USA)

65720I Develop multipurpose InGaAs focal plane array visible/SWIR camera for staring and range-gated applications [6572-17]

J. E. Nichter, Air Force Research Lab. (USA); T. J. Martin, B. M. Onat, Goodrich Corp. (USA)

65720 J MIT/LL development of broadband linear frequency chirp for high-resolution ladar [6572-18] (Keynote Paper)

K. W. Holman, D. G. Kocher, S. Kaushik, MIT Lincoln Lab. (USA) 
65720K Frequency skewed optical pulses for range detection [6572-19]

S. Ozharar, S. Gee, F. Quinlan, P. J. Delfyett, College of Optics and Photonics, Univ. of Central Florida (USA)

\section{SESSION $6 \quad$ AIRBORNE NETWORKS}

65720N Highly-integrated VCSEL-based optoelectronics for fault-tolerant self-routing optical networks [6572-22]

P. S. Guilfoyle, J. Cheng, K. Yang, K. M. Patel, D. A. Louderback, X. J. Jin, OptiComp Corp. (USA)

\section{SESSION 7 ENABLING PHOTONIC TECHNOLOGY}

657200 A $1 \times 3$ optical switch by carrier induced beam-steering on InP [6572-23]

D. A. May-Arrioja, Instituto Nacional de Astrofísica, Óptica y Electrónica (Mexico); N. Bickel, P. LiKamWa, College of Optics and Photonics, Univ. of Central Florida (USA)

65720P Programmable fiber optic splitters using distributed optical MEMS [6572-24]

N. A. Riza, S. A. Reza, College of Optics and Photonics, Univ. of Central Florida (USA)

65720Q Noncontact no-moving parts surface height measurement sensor using liquid crystal based axial scanning confocal optical microscopy[6572-25]

N. A. Riza, S. A. Khan, M. Sheikh, College of Optics and Photonics, Univ. of Central Florida (USA)

65720R Simulation and analysis of ultrafast laser pulse induced plasma generation in dielectric materials [6572-26]

J. R. Gulley, S. W. Winkler, W. M. Dennis, Univ. of Georgia (USA)

65720S Pulse shape effects on the measurement of temperature using a Brillouin-based optical fiber sensor [6572-27]

C. Galindez, F.-J. Madruga, A. Cobo, O. Conde, J.-M. Lopez-Higuera, Univ. de Cantabria (Spain)

65720T Characterization of new thermo-responsive hydrogels for optical sensing applications [6572-28]

J. C. Rueda, K. Contreras, R. Coello, Pontificia Univ. Católica del Perú (Peru); M. Lomer, Univ. of Cantabria (Spain); H. Komber, S. Zschoche, B. Voit, Leibniz Institute of Polymer Research (Germany)

$65720 U$ Single-mode photonic crystal fiber for the middle infrared [6572-29]

L. N. Butvina, O. V. Sereda, E. M. Dianov, General Physics Institute (Russia); N. V. Lichkova, V. N. Zagorodnev, Institute of Microelectronics Technology and High Purity Materials (Russia)

Author Index 
Downloaded From: https://www.spiedigitallibrary.org/conference-proceedings-of-spie on 26 Apr 2023

Terms of Use: https://www.spiedigitallibrary.org/terms-of-use 


\title{
Conference Committee
}

\author{
Symposium Chair
}

John C. Carrano, Luminex Corporation (USA)

Symposium Cochair

Larry B. Stotts, Defense Advanced Research Projects Agency (USA)

Program Track Chair

Andrew R. Pirich, Air Force Research Laboratory (USA)

Conference Chairs

Michael J. Hayduk, Air Force Research Laboratory (USA)

Andrew R. Pirich, Air Force Research Laboratory (USA)

Peter J. Delfyett, Jr., College of Optics and Photonics, University of Central Florida (USA)

Eric J. Donkor, University of Connecticut (USA)

Conference Cochairs

John P. Barrios, Air Force Research Laboratory (USA)

Rebecca J. Bussjager, Air Force Research Laboratory (USA)

Michael L. Fanto, Air Force Research Laboratory (USA)

Robert L. Kaminski, Air Force Research Laboratory (USA)

Guifang Li, College of Optics and Photonics, University of Central Florida (USA)

Hooman Mohseni, Northwestern University (USA)

Edward W. Taylor, International Photonics Consultants, Inc. (USA)

Program Committee

Henry J. Caulfield, Diversified Research Corporation (USA)

Bahram Javidi, University of Connecticut (USA)

Fazio Nash, Air Force Research Laboratory (USA)

Henry Zmuda, University of Florida (USA)

Session Chairs

1 Coherent Optical Communications

Michael J. Hayduk, Air Force Research Laboratory (USA)

Andrew R. Pirich, Air Force Research Laboratory (USA) 
2 RF Photonics

Michael L. Fanto, Air Force Research Laboratory (USA)

Hooman Mohseni, Northwestern University (USA)

$3 \quad$ Mode-locked Lasers and Optical Sources

Guifang Li, College of Optics and Photonics, University of Central Florida (USA)

$4 \quad$ Optical Detectors and Arrays

Franklyn Quinlin, College of Optics and Photonics, University of Central Florida (USA)

5 Laser Technology and Applications

Robert L. Kaminski, Air Force Research Laboratory (USA)

6 Airborne Networks

Robert L. Kaminski, Air Force Research Laboratory (USA)

$7 \quad$ Enabling Photonic Technology

Eric J. Donkor, University of Connecticut (USA) 